The University of Akron

\title{
IdeaExchange@UAkron
}

Proceedings from the Document Academy

University of Akron Press Managed

December 2016

\section{Gauguin's Savage Document Work: Understanding As Function}

Tim Gorichanaz

DrexelUniversity, gorichanaz@drexel.edu

Please take a moment to share how this work helps you through this survey. Your feedback will be important as we plan further development of our repository.

Follow this and additional works at: https://ideaexchange.uakron.edu/docam

Part of the Art Practice Commons, Library and Information Science Commons, and the Painting Commons

\section{Recommended Citation}

Gorichanaz, Tim (2016) "Gauguin's Savage Document Work: Understanding As Function," Proceedings from the Document Academy: Vol. 3 : Iss. 2 , Article 5.

DOI: https://doi.org/10.35492/docam/3/2/5

Available at: https://ideaexchange.uakron.edu/docam/vol3/iss $2 / 5$

This Conference Proceeding is brought to you for free and open access by University of Akron Press Managed at IdeaExchange@UAkron, the institutional repository of The University of Akron in Akron, Ohio, USA. It has been accepted for inclusion in Proceedings from the Document Academy by an authorized administrator of

IdeaExchange@UAkron.For more information, please contact mjon@uakron.edu, uapress@uakron.edu. 

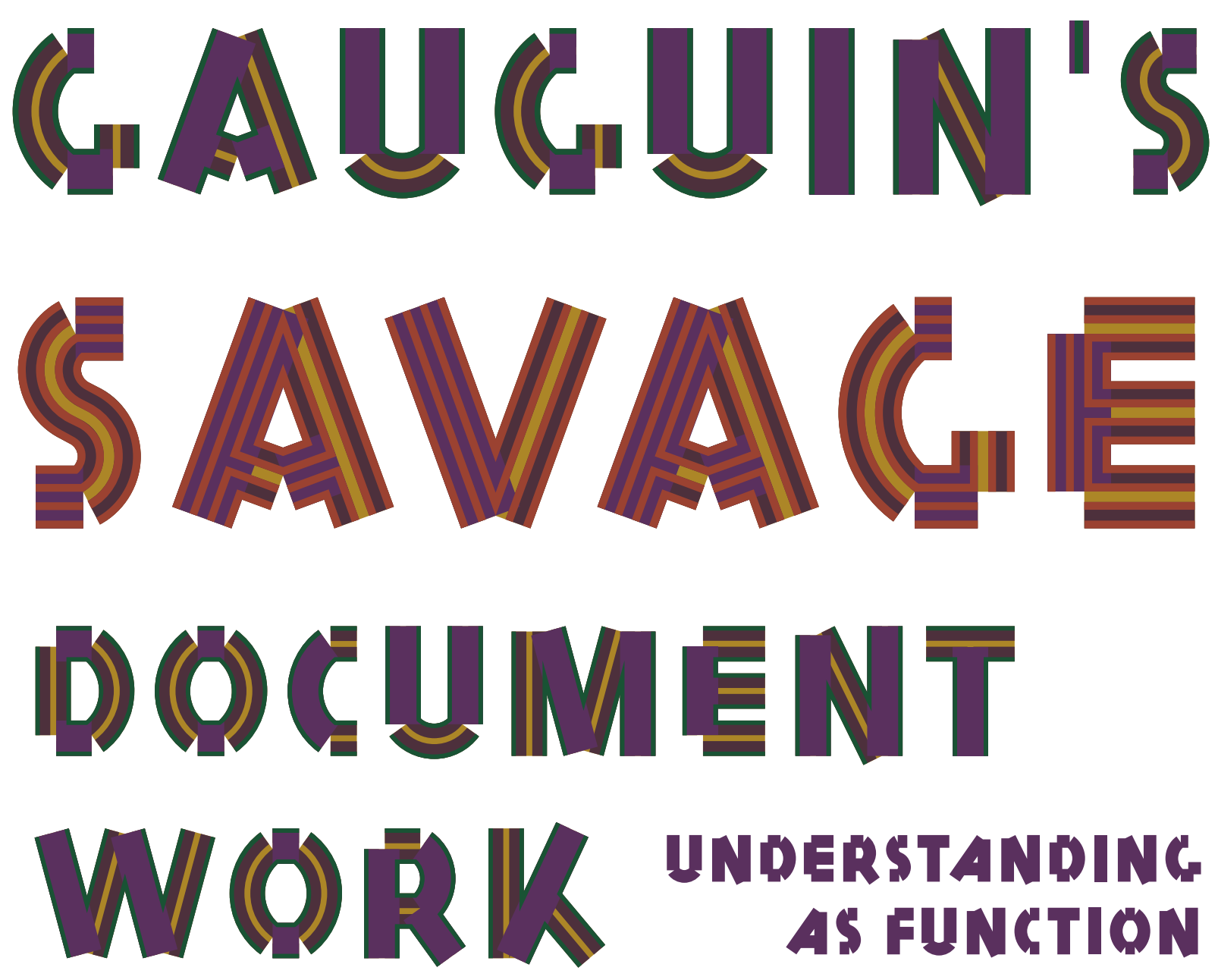

\section{UNDERSTANDING AS FUNCTION}

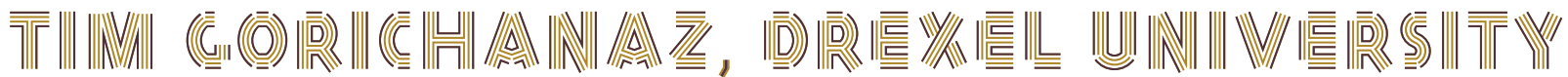

It is generally accepted that documents function as evidence. The notion of evidence can be broadly interpreted as indexical reference (Day, 2014) - that is, a thing pointing to another thing within a system. Conceptually, documentary evidence is a kind of question-answering, if only implicitly. As documentologist Jean Meyriat (1981) wrote, a thing becomes a document when a question is asked of it.

Beginning with Paul Otlet (1934), this perspective stemmed from logical positivism, which saw (and sees) documents as factual representations of aspects of the world. Of course, the concept of the document has found footing outside positivism, where it is understood more generally as a symbolic marriage of person and object. K. F. Latham and I sought to flesh this out by creating a framework of the different types of information that cohere into a document: the properties of a physical object; the discourse surrounding that object; the corporeal being of the person experiencing that object; and the memories and associations they attribute to the object (Gorichanaz \& Latham, 2016). In developing this framework, we strove for holism, careful not to let any part of the document go unaccounted for.

But our project-and seemingly all conceptualizations of the document-suffered a major oversight: In describing how a document is, we did not consider how a document could be how it is not. 
That probably sounds terribly esoteric. What I mean is, even though we had ears for the visceral and the pathic in listening to the document, we still only listened for an answer. But insomuch as there is any answer, there are always multiple answers-infinite answers, even. Sometimes (or perhaps always?), there is no answer. But as it has been conceptualized, a document provides one, single answer-at least one at a time-never mind how many answers may be "out there."

This is the issue: When we see one answer (how $d$ is), we tend to forget about the universe of other possible answers (how $d$ is not). We forget about the universe of other possible questions. Bowker and Star (2000) showed how a classification system creates order through obfuscation. That is, documents and documentary systems give answers at the cost of making the world of questioning fade into disexistence. In conceptualizing the document only in terms of what it is, the document becomes impoverished. And when we look only for answers, we enclose ourselves in an impoverished view of the world, ignorant of the great mystery of being.

So maybe our only recourse is to forget about documents.

Or maybe there's another way to think about documents-not in terms of what they concretize, but in terms of what they leave behind. Could a document ever show what it doesn't show? Can a document, a single thing, evoke the wholeness of the world? Could a document not only answer-but question? The prospect may seem ludicrous. The vast mass of beingness that does not cohere in any given document is infinite and undifferentiated. How, then, can it be approached?

James Joyce said that in the particular is contained the universal (Power, 1944). But one has to have an eye for the universal to see it in the particular. Too often, we have an eye only for the particular. This was the impetus for Martin Heidegger's (1977) essay “The Question Concerning Technology.” In this essay, Heidegger argues that, in the industrialized West, we tend to see the world as a resource that we can put to use. Regarding the world in this way, we see only what is revealed and forget about what is left unrevealed. In the lumber, we lose the tree. In the pork, we lose the pig. In terms of my discussion here: In the answer, we lose the question. As Heidegger suggests, the problem is not in forestry, farming or answering, but rather in the way we come to these activities. There is an alternative to seeing the world as our resource; that alternative is being immersed in the mystery of the world. That is, as Rainer Maria Rilke (2004) wrote, living and loving the question.

Heidegger (1977) paints a grim picture of our society-one that is hard to refute. Our seeing the world as a resource rather than part of us has contributed to seemingly irreversible climate change. We are troubled by alienation, consumerism and violence. Our belongingness is constantly under threat. What can be done? In the final pages of his essay, Heidegger suggests that works of art can nurture our questioning nature-if only we can overcome seeing them, too, as resources, which nowadays we are inclined to do. But how can this be achieved?

Decades before Heidegger, the artist Paul Gauguin struggled with this same question. Gauguin decried the art that was being praised by his contemporaries, seeing it as lifeless-it was correct, but untrue. Gauguin sought to develop a different kind of art—and, along with it, a different kind of people. 
Today, Gauguin is regarded as a harbinger of modern art, weaving a flag later borne by the likes of Marcel Duchamp and Pablo Picasso. But we still seem-too often, on the whole-to see the world as a resource. If, as Heidegger writes, "questioning builds a way" (1977, p. 311), then the question, to me, is: How can we cultivate in people a love of questioning?

Gauguin, sadly, did not succeed in instilling such a love across all of society, but he certainly did so within himself. In this essay, I explore one way he did this: his art-making process. It is my hope that this exploration will point a way forward.

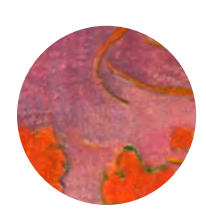

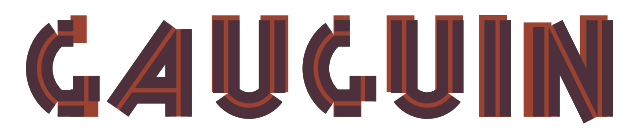

When Paul Gauguin was eighteen months old, his family moved to Peru. In Lima, young Gauguin became enchanted by the Incan ceramic art that was beloved and collected by his mother but disparaged by the other Europeans there. His family returned to France when he was seven, and this enchantment lay dormant for several decades.

As a young man, Gauguin took a job as an accountant at the Paris stock exchange. He found material success, and he married and had five children. By serendipity or design, he lived in the same neighborhood as the Impressionists. He became friends with a few of them, and began painting with the likes of Pissarro and Degas in his free time-and dealing in art on the side.

The stock market crashed in 1882, May shaking Gauguin awake. Not long after, he the day come (soon resolved to make a living from painting perhaps) when I'll flee to the full-time. Despite many challenges, Gauguin pursued his art. Still, he was dissatisfied with it, calling it "incomplete" (Gauguin \& Guérin, 1996, p. 41). He was also growing disillusioned with European society, and his relationship with his wife began to flounder. They separated. Still he pursued his art, experimenting with different styles, incorporating aspects of the exotic art he loved. His skill and satisfaction improved, but he had yet to find recognition, acceptance or woods on an island in Oceania, there to live on ecstasy, calm, and art. With a new family by my side, far from this European scramble for money. There, in Tahiti, in the silence of the beautiful tropical nights, I will be able to listen to the soft murmuring music of the movements of my heart in amorous harmony with the mysterious beings around me. Free at last, without financial worries and able to love, sing, and die. (Gauguin any semblance of financial stability. He lived in \& Guérin, 1996, p. 40) poverty, taking up odd jobs to make ends meet. But

Gauguin saw a glimmer of the future after a brief visit to Martinique, a Caribbean island, where he painted a series of tropical images that proved salable and even came to be lauded.

With his palate whetted (and palette wetted), Gauguin defected to Tahiti in 1891, where he sought to reprise tenfold his experience in Martinique, aiming for nothing less than "to become a savage and create a new world" (Gauguin, 1997, p. 17). "I will be reinvigorated out there," he promised a friend (Gauguin \& Guérin, 1996, p. 41). He installed himself in a bamboo hut, in which he lived and made art. He created drawings, prints, paintings and sculptures, pioneering techniques along the way, and he also created books which were meant to help the public appreciate his work. Save for a two-year return to France, Gauguin never left Tahiti. He lived out his dream of savage artistic exploration, which offered him solace even in the face of continued financial distress and declining health. He died suddenly in 1903, at age fifty-four. 


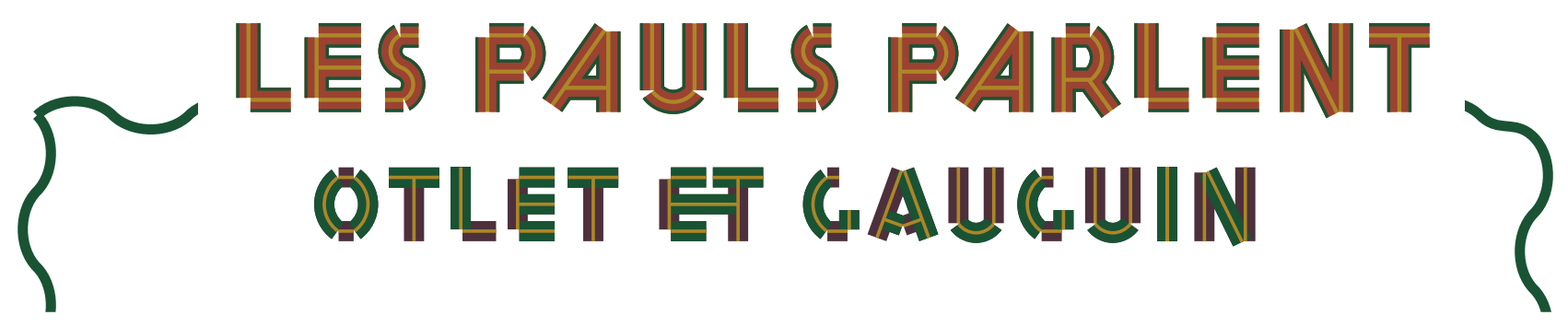

Paul Otlet (1868-1944) was the father of information science. He pioneered the concept of the document, recognizing that many things beyond merely books are informative, including works of art (Otlet, 1934). Otlet saw documents as containers for facts-representations of the world. Though he admitted literature and art into his concept of the document, Otlet had a very different understanding of art than Paul Gauguin (1848-1903). The two Pauls were rough contemporaries in nineteenth-century Francophone Europe, but even so, they walked in different worlds. This section presents an imagined dialogue between the two Pauls, fashioned from direct quotations of both men.

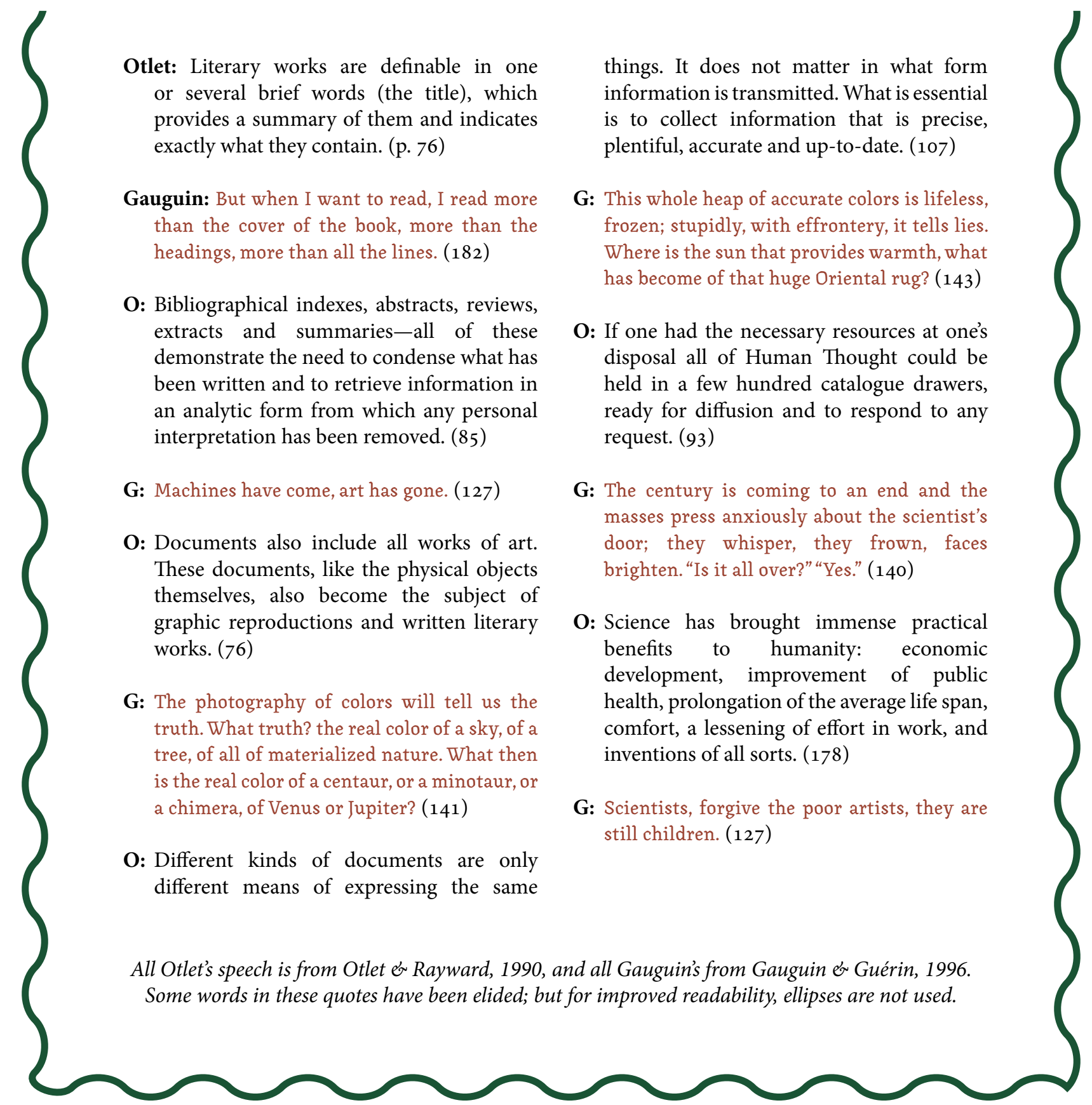




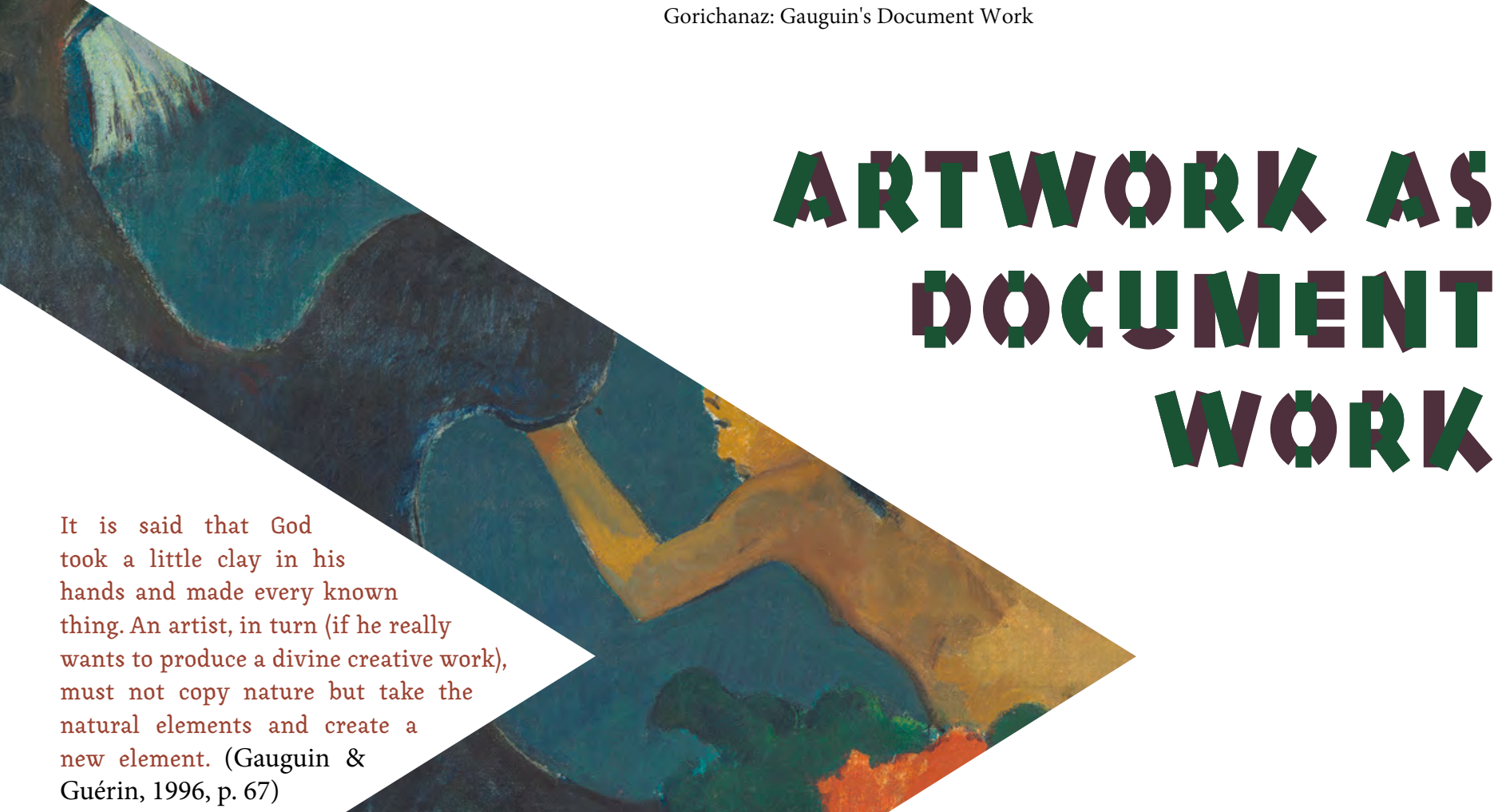
Guérin, 1996, p. 67) 
merely reproduction; it was transformation. As described by art historian Richard Brettell (2007), such productive reproduction was central to Gauguin's process, allowing him to internalize the lessons of artists he admired rather than merely mimicking them. Gauguin characterized his own process with a hint of self-deprecation when he wrote: "He traces a drawing, then he traces this tracing, and so on till the moment when, like the ostrich, with his head in the sand, he decides that it does not resemble the original any longer. Then!! he signs" (Gauguin, 1997, p. 29).

A clear example of Gauguin's productive reproduction can be seen in some of his depictions of the Biblical Eve, shown here. The painting Te Nave Nave Fenua (1) was made around the same time as the sculptural version (2). Years later, Gauguin created a series of woodblock prints based on the painting (3-5), as he did with many of his most valued paintings. Later still, he created a watercolor monotype depiction of the figure (6). But as Figura (2014) points out, the originary visual model for Eve in all these depictions was a depiction of the Buddha in a relief from the temple of Borobudur in Java (7), a photograph of which Gauguin had in his possession.
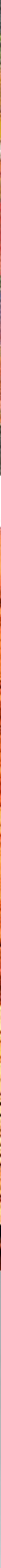


\section{DOCQUMIENT WORK AS QUESTIONINC.}

Yet if I believe I have

found a great deal,

then logically I must

conclude that there

still remains a great

deal to be found. (Gauguin \& Guérin, 1996, p. 142)

I am led to wonder why Gauguin returned again and again to the Buddha-turned-Eve in his art. Art historian Wayne Andersen (1996) sees this as part of Gauguin's quest to discover his origins. Indeed, Gauguin himself said he had a "terrible itch for the unknown" (Gauguin \& Guérin, 1996, p. 33). A premier example of how questioning suffuses Gauguin's work is his monumental piece, which was meant to be the last of his life (Gauguin \& Guérin, 1996, p. 159), entitled Where Do We Come From? What Are We? Where Are We Going?

But why did Gauguin pursue his questioning through document work? What did document work allow him to do that could not be done through, for instance, pure thought?

The function of a document, as discussed above, is to provide an answer. This means the function of a document rests in its meaning. What, then, is the function of document work? To foment meaning. So far, investigators of document work have focused on the gnostic (conceptual, cognitive, procedural) meaning fomented through document work-the answers it engenders.

But we know that documents are more than merely gnostic. Surely this means that document work can be, too. Does non-gnostic document work give something other than answers? Van Manen (2014) argues that experiences can have pathic (inceptual, emotional, ontological) meaning, and that questioning is one way of finding it. Thus, insomuch as document work is an experience, it may foment pathic meaning through questioning. For a better view of how document work can be a catalyst for questioning, we can go again to Gauguin.

In Gauguin's view, the accepted art of his day only showed the outward appearance of things. He did not see this as a virtue. As Gauguin observed, "when you recopy a sketch you are pleased with, one that you did in a minute, in a second of inspiration, all you get is an inferior version, especially if you correct its proportions, the mistakes that reason imagines it sees" (Gauguin \& Guérin, 1996, p. 180). Indeed Impressionism, which was in vogue in Gauguin's time, overtly aligned itself with the science of optics.

Gauguin wrote that "a painter's literary poetry is special, and not the illustration or the translation, through shapes, of something written. In other words, what you should try for in painting is suggestion rather than description, just as in music" (Gauguin \& Guérin, 1996, p. 211). Gauguin provided more detail on this in an earlier writing: "I arrange lines and colors so as to obtain symphonies, harmonies that do not represent a thing that is real, in the vulgar sense of the word, and do not directly express any idea, but are supposed to make you think the way music is supposed to make you think, unaided by ideas or images, simply through the mysterious affinities that exist between 


\section{Que Somines Nous}

our brains and such arrangements of colors and lines" (Gauguin \& Guérin, 1996, p. 109). All this is to say that, instead of representing, Gauguin sought to present; instead of showing outward appearance, Gauguin sought to show inner truth (Gauguin \& Guérin, 1996, pp. 141-145). Discerning inner truth requires asking questions, but not the kind that are satisfied by answersrather, the kind that reverberate, expand, unfold and deepen. The kind of question that asks itself and asks itself and asks itself.

One way Gauguin sought to discern inner truth was through internalizing his reference material and allowing it to resurface on its own. As discussed above, in his artwork he reproduced depictions and motifs-both from others and his earlier work. He employed his reference documents in an observable way. And yet time and again he asserted that he drew and painted without models (Gauguin \& Guérin, 1996, pp. 141-145). He went so far as to say, "Everything I do springs from my wild imagination" (Gauguin \& Guérin, 1996, p. 204). And yet on another occasion, he admitted, "Who can swear that something I have thought, or read, or enjoyed did not influence one of my works several years later?" (p. 128). What can be made of this? It would seem that Gauguin worked to internalize his reference material, keeping within his conscience only their essential structure, their inner truth (Danielsson, 1969).

But this wasn't merely a mental practice. Rather, his internalization was proven, so to speak, when it was re-externalized. Only then, given time and distance, could he appraise it. Gauguin wrote as much early in his tenure in Tahiti: “I've simplified so much that by now I don't know how to judge the result. It seems disgusting to me. Once I'm back, with carefully dried canvases, frames, etc., and all the eloquent accoutrements, then I'll judge" (Gauguin \& Guérin, 1996, p. 54).

This was an iterative process: "In art, these sacrifices have to be made, stage by stage-groping efforts, half-formed thoughts lacking direct and definitive expression. Bah! for a minute you touch the sky and then it slips away afterward; yet this glimpse of a dream is something more powerful than any matter" (Gauguin \& Guérin, 1996, p. 41).

In this light, we can see each production of the Tahitian Eve discussed earlier as, for Gauguin, another step toward discerning the essential structure, the inner truth, of what lay beyond the image. To step forwards, rather than laterally or backwards, it was necessary to experiment with different compositions, techniques and materials. Other artists, such as those esteemed by the École in Paris, sketched as a way to refine their ideas, beginning with rough gestures and working toward visual determinism.

But Gauguin went in the opposite direction. Working toward visual ambiguity, it seems, was a way to unlock inner truth.

Gauguin's valorization of the artistic process on his questioning quest can be seen most brightly in his oil transfers. Oil transferring was a process he invented, which was somewhere between drawing and printing. First, a piece of paper was coated in printer's ink. A second piece of paper was then set on 
Since the advent of the snapshot, said one

horse lover, painters have been able to understand horses, and Meissonnier, one of the glories of France, has been able to depict that noble animal from all angles. As for myself, my art goes way back, further than the horses on the Parthenon - all the way to the dear old wooden horse of my childhood. I also began to hum the sweet music from one of Schumann's children's pieces, "The Wooden Horse."

(Gauguin \& Guérin, 1996, p. 127).

top of it. Now the artist drew a picture on the second piece of paper. As the artist drew, oil from the bottom sheet was transferred to the bottom side of the top sheet. This became the displayed, finished piece-a reverse image of what the artist drew. As Figura (2014) writes, Gauguin was fascinated by the elements of chance in the process: the unpredictability of the transfer, which was anything but a precise reversal of what was drawn, and the serendipitous marks and textures that arose. Things were lost, and things were gained-like the work of the Hindu deity Shiva, the act of creation was also an act of destruction. Gauguin's oil transfers "confirm that for Gauguin it was the creative process itself-the process of taking one thing and working to transform it into something radically new-that mattered above all else" (Figura, p. 32). The somewhat chance-based end product then contributed to new documentary reference material that Gauguin could analyze and internalize in his continued quest for inner truth.

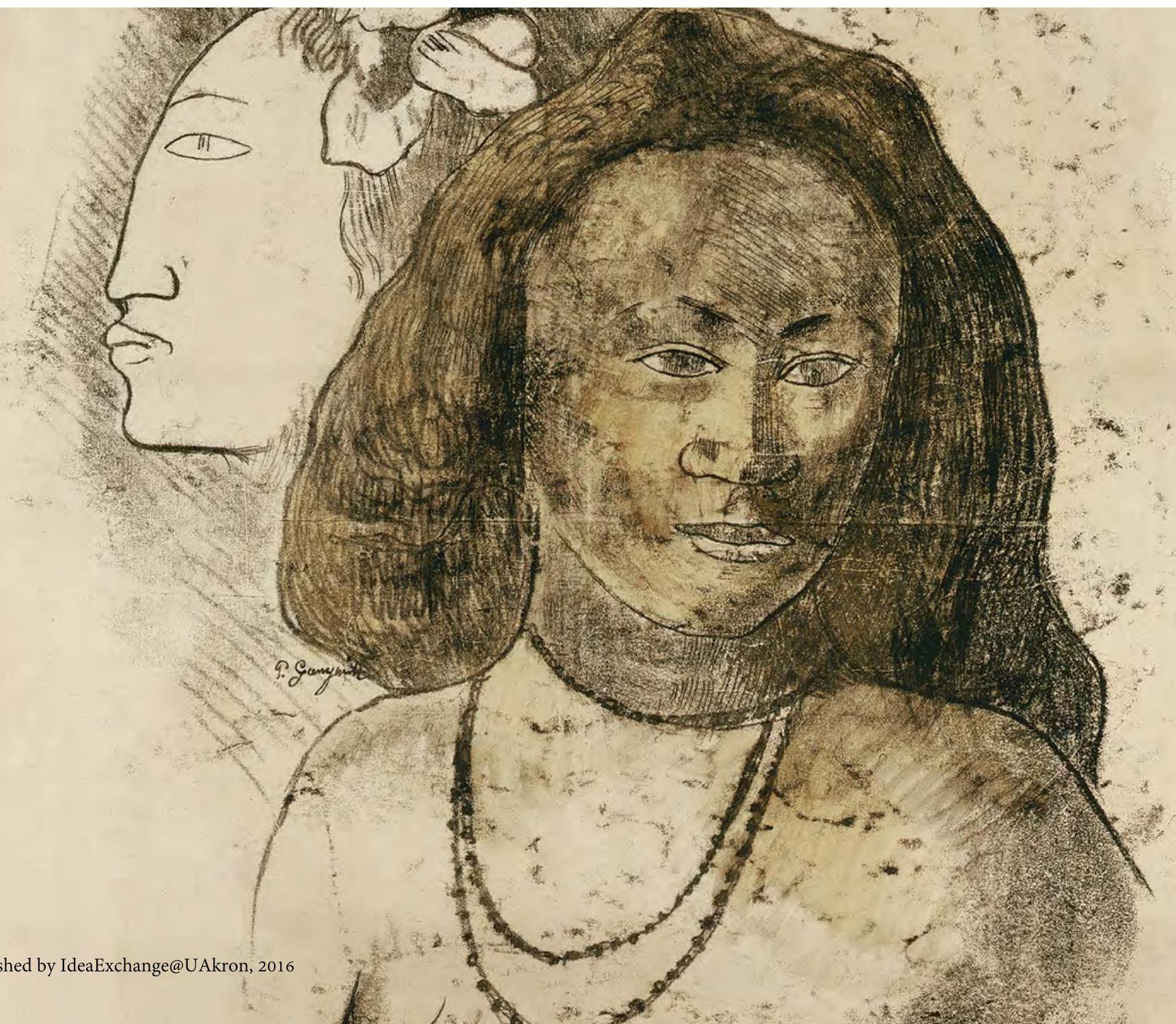




\section{III :II:IIIII:

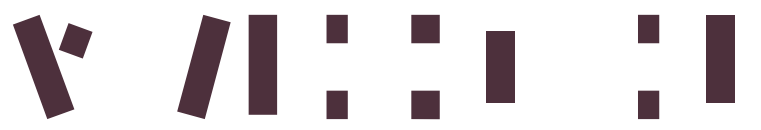 DUIESTIONING AS A MODE OF IIII:III WNDERSTANDING}

Before he went to Tahiti, disillusioned in France, Gauguin wrote, "Right now I am letting all my artistic intelligence lie fallow and I doze, I am not ... disposed to understand anything" (Gauguin \& Guérin, 1996, p. 42). Doing art-that is, carrying out document workwas somehow connected to understanding.

Many artists do experimentation, testing, trying... Like Gauguin, many artists riff on recurring motifs in their work throughout their careers. Exploring their subjects in new ways, in new mediums. Why should this be? As we saw with Gauguin, such document work was a matter of continued questioning. But it is not the same exact question over and over again. Rather, it is progressively inflected, deepened. The question shifts as the document worker builds understanding.

A recent definition of understanding for the information sciences, drawn from the philosophy of information, suggests that understanding is built by conscious entities as they come to appreciate an interconnected body of knowledge (Bawden \& Robinson, 2016). By this definition, we can see an artist's understanding as their appreciation of the diverse ways an essential truth has been manifest in their work.

But it seems to me that understanding is also questioning. I have written earlier on the crushing weight of the unknown that accompanies the acquisition of knowledge: "The more I read, the more questions I have. The more I know, the more I don't know... Because, as I'm collecting knowledge, I'm also collecting ignorance" (Gorichanaz, 2016).

Though my proportion of knowledge to ignorance is precipitously falling, I think my understanding is on the rise. This has been the case for me in my studies, and it was the case for Gauguin in his artwork. And it seems to be the case with document work generally. As document work is done, some knowledge is gained-and along with it, innumerable questions. Just as with the document itself, the questions are usually forgotten in the face of the allure of the 
answer. If we can pay heed to the way paved by questioning, as Heidegger (1977) counseled, then we may find our very salvation down the road: "The more questioningly we ponder the essence of technology, the more mysterious the essence of art becomes. 9 The closer we come to the danger, the more brightly do the ways into the saving power begin to shine and the more questioning we become. For questioning is the piety of thought" (Heidegger, 1977, p. 341).

But Gauguin did not carry out his document work only for his own sake. Rather, he hoped his work would build understanding in others as well. Indeed, he said so explicitly: "Ah, if only the good public would finally learn to understand a little, how I would love it!” (Gauguin \& Guérin, 1996, p. 148). To this end, Gauguin published Noa Noa and Ancien Culte Mahorie, books meant to communicate what was for him the meaning of Tahiti; he hoped his readers, thus edified, would come to his artwork in a more receptive frame of mind (Andersen, 1996).

Time and again, however, Gauguin was discouraged. In one of his notebooks, he wrote: "The public wants to understand and learn in a single day, a single minute, what the artist has spent years learning" (Gauguin \& Guérin, 1996, p. 67). And later: "I am sometimes reproached with being incomprehensible precisely because people look for an explanatory meaning in my paintings, whereas there isn't any" (Gauguin \& Guérin, 1996, p. 211). In other words, Gauguin was discouraged when people looked for answers in his art rather than questions.

But he remained hopeful, I think, that his project of the cultivation of understanding would be taken up by his spiritual descendants. In his last letter, days before his death, Gauguin wrote, "It is true that I know so little! But I prefer that little, which is of my own creation. And who knows whether that little, when put to use by others, will not become something big?" (Gauguin \& Guérin, 1996, p. 294).

And so we are left where Gauguin left off-and Heidegger, too. How can engagement be encouraged? How can questioning be instilled? How can wonderment flourish? With work and interest, we can do these for ourselves-but where does that leave the rest of society?

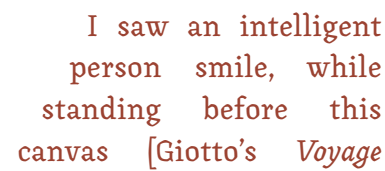
to Marseilles]; then, looking at me, with the smile on his lips, he said to me: "Do you understand that?" I answered the way I still answer today: "There is nothing to understand. Just like listening to music. If all these figures were their true size, if the sea were a true sea, if the faces were true flesh, then you would understand! I don't think you would, for the laws of beauty are not to be found in all those truths; therefore, neither is understanding, and you must look elsewhere for feelings to satisfy you. (Gauguin \& Guérin, 1996, pp. 132-133) 


\section{REFERENCES}

\section{TEXTS}

Andersen, W. (1996). Introduction. In P. Gauguin and D. Guérin (Ed.), The writings of a savage (E. Levieux, Trans.) (pp. ix-xxxii). Cambridge, MA: Da Capo Press.

Bawden, D., \& Robinson, L. (2016). "A different kind of knowing": Speculations on understanding in light of the philosophy of information. Paper presented at CoLIS9, June, Uppsala, Sweden.

Björk, L. (2015). How reproductive is reproduction? Digital transmission of text-based documents [Doctoral dissertation]. Borås, Sweden: The Swedish School of Library and Information Science.

Bowker, G., and Star, S. L. (2000). Sorting things out: Classification and its consequences. Cambridge, MA: The MIT Press.

Brettell, R. R. (2007). Gauguin and paper: Writing, copying, drawing, painting, pasting, cutting, wetting, tracing, inking, printing. In S. F. Eisenman (Ed.), Paul Gauguin: Artist of myth and dream (pp. 59-67). New York: Rizzoli International.

Danielsson, B. (1969). The exotic sources of Gauguin's art. Expedition Magazine, 11(4). Retrieved from http://www. penn.museum/sites/expedition/? $\mathrm{p}=2030$

Day, R. E. (2014). Indexing it all: The subject in the age of documentation, information, and data. Cambridge, MA: The MIT Press.

Figura, S. (2014). Gauguin's metamorphoses: Repetition, transformation, and the catalyst of printmaking. In $\mathrm{K}$. Bentley (Ed.), Gauguin: Metamorphoses (pp. 14-35). New York: Museum of Modern Art.

Frohmann, B. (2004). Documentation redux: Prolegomenon to (another) philosophy of information. Library Trends, 52(3), 387-407.

Gauguin, P. (1997). Gauguin's intimate journals (V. W. Brooks, Trans.). Mineola, NY: Dover Publications.

Gauguin, P., \& Guérin, D. (Ed.). (1996). The writings of a savage (E. Levieux, Trans.). Cambridge, MA: Da Capo Press.

Gorichanaz, T. (2015). For every document, a person: A co-created view of documents. Proceedings from the Document Academy, 2(1), paper 9. Retrieved from http:// ideaexchange.uakron.edu/docam/vol2/iss1/9/

Gorichanaz, T. (2016). Bliss, and so much more. Medium. Retrieved from https://medium.com/@timgorichanaz/ bliss-and-so-much-more-3f68d106ec69

Gorichanaz, T., \& Latham, K. F. (2016). Document phenomenology. Journal of Documentation, 72(6), 11141133.

Heidegger, M. (1977). The question concerning technology. In D. F. Krell (Ed.), Basic writings (pp. 307-341). New York: HarperCollins.
Meyriat, J. (1981). Document, documentation, documentologie. Schéma et Schématisation, 2(14), 51-63.

Otlet, P. (1934). Traité de documentation: Le livre sur le livre: Théorie et pratique [Treatise on documentation: The book on the book: Theory and practice]. Brussels: Editiones Mundaneum, Palais Mondial.

Otlet, P., \& Rayward, W. B. (Ed.). (1990). International organisation and communication of knowledge: Selected essays of Paul Otlet (W. B. Rayward, Trans.). Amsterdam: Elsevier.

Power, A. (1944). From the old Waterford house. London: Mellifont.

Rilke, R. M. (2004). Letters to a young poet (M. D. H. Norton, Trans.). New York: W. W. Norton \& Company.

Sweetman, D. (1996). Paul Gauguin: A life. New York: Simon \& Schuster.

van Manen, M. (2014). Phenomenology of practice: Meaninggiving methods in phenomenological research and writing. Walnut Creek, CA: Left Coast Press.

\section{IMACES (BY PACE NUMBER)}

2. Paul Gauguin, Parau na te Varua Ino (Words of the Devil), oil on canvas, 1892, National Gallery of Art, Washington

3. Ibid.

5. Paul Gauguin, Fatata te Miti (By the Sea), oil on canvas, 1892, National Gallery of Art, Washington

6. 1. Paul Gauguin, Te Nave Nave Fenua (The Delightful Land), oil on canvas, 1892, Ohara Museum of Art, Kurashiki, Japan

2. Paul Gauguin, Tehamana (Head of Tehura), wood carving, 1892, Musée d'Orsay, Paris

3. Paul Gauguin, Nave Nave Fenua (Delightful Land), woodblock print, 1893-4, National Gallery of Art, Washington

4. Paul Gauguin, Nave Nave Fenua, woodblock print, 1893-4, The Museum of Modern Art, New York

5. Paul Gauguin, Nave Nave Fenua, 1893-4, The Art Institute of Chicago

6. Paul Gauguin, Nave Nave Fenua, watercolor monotype, 1894, Museum of Fine Arts, Boston

7. Isidore van Kinsbergen, Reliefs from the temple of Borobudur, photograph, 1874, Fabrice Fourmanoir Collection, Papeete, Tahiti

8. Paul Gauguin, Where Do We Come From? What Are We? Where Are We Going?, oil on canvas, 1897-8, Museum of Fine Arts, Boston

9. Paul Gauguin, Tahitian Woman with Evil Spirit, oil transfer monotype, 1899-1900, Städel Museum, Frankfurt am Main, Germany

12. Paul Gauguin, Soyez Mystérieuses (Be Mysterious), wood carving, 1890, Musée d'Orsay, Paris 